\title{
PAMIĘĆ O HOLOKAUŚCIE NA PODKARPACIU NA POCZĄTKU XXI WIEKU NA PRZYKLADZIE OBCHODÓW ROCZNICOWYCH
}

DOI: $10.15290 /$ sp.2016.24.09

Słowa kluczowe: pamięć zbiorowa, Holokaust, Podkarpacie, obchody rocznicowe

„Jesteśmy tutaj, aby pamiętać" 1

Michael Schudrich

\section{Uwagi wstępne}

Artykuł stanowi analizę sposobu, w jaki Holokaust, jako wydarzenie graniczne, traumatyczne i przekształcające ${ }^{2}$, które zaznaczyło się w historii nie tylko regionu, kraju, ale również kontynentu, staje się elementem pamięci zbiorowej mieszkańców Podkarpacia. Pamiętając o tym, że "przeszłość w kontekście praktyki społecznej podlega interpretacji z punktu widzenia teraźniejszych potrzeb i stanowi źródło wzorców i wartości ważnych z punktu widzenia żyjących pokoleń" ${ }^{3}$, podjęta została próba odpowiedzi na pytania: jak realizowana jest lokalna polityka upamiętnień na podstawie rocznicowych obchodów Holokaustu? Czy są to scentralizowane, odgórne działania lokalnych władz lub innych instytucji państwowych, czy też różnorodne, spontaniczne, oddolne reakcje społeczne? Jaka jest rola lokalnych instytucji

1 Z wystąpienia rabina podczas Marszu Żywych w Rzeszowie w 2006 r. za: A. Adamski, Żyjemy, aby pamiętać, „Nowiny” 10.07.2006, s. 19.

2 K. Bojarska, Zagłada, [w:] Modi Memorandi. Leksykon kultury pamięci, red. M. Saryusz-Wolska, R. Traba, Warszawa 2014, s. 538.

3 P. T. Kwiatkowski, Pamięć zbiorowa społeczeństwa polskiego w okresie transformacji, Warszawa 2008, s. 305. 
kształtujących regionalną pamięć zbiorową? Jakie grupy społeczne są zainteresowane cyklicznym wspominaniem Holokaustu i oddawaniem czci jego ofiarom w szeroko rozumianej przestrzeni publicznej, a jakie grupy społeczne są odbiorcami tych upamiętnień? Jaka wiedza o zagładzie Żydów przekazywana jest tamtejszej społeczności przez obchody oraz jaki ma ona wpływ na kształtowanie tożsamości mieszkańców Podkarpacia? ${ }^{4}$

Na obszar terytorialny, którego dotyczy niniejszy artykuł - województwo podkarpackie w swych granicach administracyjnych z 1999 r. - przed wojną składały się powiaty województw lwowskiego i krakowskiego. W czasie II wojny światowej tereny te po licznych zmianach administracyjnych weszły w skład dystryktu krakowskiego w Generalnym Gubernatorstwie, a od marca 1945 r. - utworzyły województwo rzeszowskie powstającego państwa polskiego.

Tak więc Podkarpacie jako nowo powstały region pogranicza, czyli zjawisko nie tylko w sensie geograficznym i politycznym, ale również kulturowym i społecznym ${ }^{5}$, głównie o charakterze administracyjnym, którego granice nie pokrywają się z granicami obszarów historycznych, występujących na tym terytorium, jest organizmem, który ciągle poszukuje swojej tożsamości kulturowej, co ma wpływ na regionalny kontekst pamięci zbiorowej - „na regionalny wymiar naznaczania przestrzeni oraz pamięci o wydarzeniach i postaciach ważnych dla regionu" ${ }^{\prime}$.

W niniejszym tekście wykorzystano artykuły prasowe publikowane głównie w prasie lokalnej w latach 2000-2015. Kwerenda objęła: „Gazetę Wyborczą" wydanie rzeszowskie, „Wyborczą.pl”, „Nowiny", „Nowiny24.pl”, "Super Nowości”, „Tygodnik Extra”, „Niedzielę" oraz materiały archiwalne zgromadzone przez organizatorów analizowanych obchodów i materiały informacyjne publikowane przez nich na stronach internetowych: www.pwste. edu.pl, www.ipn.gov.pl, www.podkarpackie.pl.

4 Ważnym uzupełnieniem tematu, wymagającym dalszych badań byłyby analiza lokalnych obchodów rocznicowych Holokaustu skupiona na okresie od pierwszych, tużpowojennych upamiętnień po okres transformacji oraz porównanie obchodów rocznicowych Holokaustu po 1989 r. na Podkarpaciu z innymi lokalnymi uroczystościami rocznicami, takimi jak np. walki partyzanckie w czasie II wojny światowej czy kult „żołnierzy wyklętych".

5 K. Malicki, Pamięć przeszłości pokolenia transformacji, Warszawa 2012, s. 131.

6 Tegoż, Polacy i ich pamięć przeszłości. Studium socjologiczne pamięci zbiorowej na przykładzie regionu podkarpackiego, Kraków 2012, s. 30. 


\section{Pamięć zbiorowa a Holokaust}

Niemiecka kulturoznawczyni i badaczka kulturowego znaczenia pamięci ${ }^{7}$ Aleida Assmann rozróżnia pamięć indywidualną, która jest „dynamicznym medium subiektywnego przepracowania doświadczeń" ${ }^{\prime} \mathrm{i}$ jest niejako podporządkowana drugiej kategorii - pamięci pokoleń, która z kolei podziela $\mathrm{w}$ ramach pokolenia własne, specyficzne „poglądy na świat i sposoby jego porządkowania" ${ }^{\prime}$. Trzecią kategorią jest pamięć zbiorowa oraz rodzaj tej pamięci - pamięć lokalna (regionalna). Dwie ostatnie kategorie będą szczególnie interesujące $\mathrm{w}$ kontekście problematyki niniejszego artykułu.

Różne instytucje, organizacje, narody i kraje tworzą własną pamięć zbiorową przez odnoszenie się za pomocą symboli, rytuałów, praktyk i znaków do materialnych, symbolicznych i funkcjonalnych miejsc pamięci lub miejsc upamiętnienia. To miejsca, w których „dokonywały się wydarzenia i procesy godne upamiętnienia i/lub takie, w których podejmowane były/są akty komemoracji" (to: pomniki, tablice, zabytki, cmentarze, groby), ale to również wydarzenia, procesy, symbole, rzeczywiste i wyobrażone postacie, w których "kanalizuje się narodowe dziedzictwo"10. W ten sposób jednostkom i całym społecznościom są przekazywane i wpajane określone treści, czyniąc $\mathrm{z}$ ich odbiorców nosicieli pamięci zbiorowej, a podmioty tworzące pamięć zbiorową uzyskują własną tożsamość. Według Assmann pamięć zbiorowa służy osiągnięciu określonych celów. Nie jest spontaniczna i nie przyjmuje dowolnych wspomnień, traktując zapominanie jako ważny element

7 Badania na temat społecznego i kulturowego znaczenia pamięci (memory studies) zapoczątkował M. Halbwachs, $L a^{\prime}$ mémoire collective, Paris 1950. Do kanonu literatury należą również m.in. prace: P. Nora, Les Lieux de memoire, Paris 1984; F. Ankersmit, Narracja, reprezentacja, doświadczenie. Studia z teorii historiografii, red. i wstęp E. Domańska, Kraków 2004; P. Ricoeur, Pamięć, historia, zapomnienie, tłum. J. Margański, Kraków 2006; J. Assmann, Pamięć kulturowa. Pismo, zapamiętywanie i polityczna tożsamość w cywilizacjach starożytnych, tłum. A. Kryczyńska-Pham, Warszawa 2008; D. LaCapry, Historia w okresie przejściowym. Doświadczenie, tożsamość, teoria krytyczna, tłum. K. Bojarska, Kraków 2009. Na gruncie polskiej humanistyki wkład w badania nad teorią pamięci wnieśli m.in.: N. Assorodobraj-Kula, "Żywa historia". Świadomość historyczna: symptomy i propozycje badawcze, "Studia Socjologiczne" 1963, nr 2 (9), s. 5-45; M. Kula, Nośniki pamięci historycznej, Warszawa 2002; B. Szacka, Czas przeszły, pamięć, mit, Scholar, Warszawa 2006; K. Pomian, Historia. Nauka wobec pamięci, Lublin 2006.

8 A. Assmann, Między historia a pamięcią. Antologia, Warszawa 2013, s. 43.

9 Tamże, s. 47.

10 K. Kończal, Miejsce pamięci, [w:] Modi Memorandi..., s. 230. 
budowania określonego obrazu. Jest to pamięć "przemyślanego wyboru” i często bywa upolityczniana. Pamięć ta dąży do konfrontacji z innymi pamięciami. Ujednolicona i uogólniona, z rozbudowaną symboliką odwołującą się do silnych emocji oraz wywołująca emocje, łatwiej jest utrwalana i przekazywana następnym pokoleniom ${ }^{11}$.

Pamięć regionalna/lokalna (terminy stosowane zamiennie $\mathrm{w}$ stosunku do historii lokalnej i regionalnej) jest z kolei pamięcią charakterystyczną dla danej społeczności terytorialnej. Pozostaje w ścisłym związku z jej aktualną sytuacją kulturowo-gospodarczą, wyróżnia ją spośród innych wspólnot i afirmuje, ale przede wszystkim jest odpowiedzią tej społeczności na potrzebę wspominania wybranych aspektów lokalnej i regionalnej przeszłości, by stać się elementem tworzącym miejscową tożsamość społeczną. Ten typ upamiętnienia jest wspierany przez działalność państwowych i samorządowych instytucji kultury i nauki (muzeów, archiwów, uczelni wyższych, szkół, bibliotek, izb pamięci), kościelnych lub jako ruch oddolny - realizowany przez inicjatywy społeczne bądź indywidualne (np. działalność historyków-regionalistów) ${ }^{12}$. Na treści tej pamięci składają się zjawiska istotne zarówno lokalnie, jak i ponadlokalnie, dlatego pamięć ta może być traktowana jako swoisty „papierek lakmusowy postaw wobec przeszłości"13.

Holokaust - masowe ludobójstwo ok. 6000000 europejskich Żydów, przeprowadzone przez Niemców podczas II wojny światowej, pochłonęło nie mniej niż 2700000 polskich Żydów. Ocalało nie więcej niż $425000^{14}$ polskich Żydów. Skala zbrodni, będącej z założenia sprawców nie tylko unicestwieniem ludzi, ale również pamięci o nich, sprawia, że Holokaust jest przez historyków uważany za wydarzenie przekształcające podstawowe kategorie kultury, sposoby myślenia, tożsamości i pamięci. To wydarzenie, które stanowi cezurę historii, przerywa jej bieg i wprowadza nowy porządek $^{15}$. To wreszcie według Zygmunta Baumana „wydarzenie, które określa kształt nowoczesnego świata i którego skutki są odczuwalne - nawet jeśli nieuświadomione - dla każdego, kto w tym świecie żyje. Tak rozumiane wydarzenie doprowadziło do radykalnego zachwiania opowieści o postępie $\mathrm{w}$ historii, nie będąc powrotem do barbarzyńskich praktyk przednowo-

\footnotetext{
11 A. Assmann, Między historią..., s. 48-50.

12 K. Woniak, Pamięć lokalna, [w:] Modi Memorandi..., s. 340.

13 K. Malicki, Polacy i ich pamięć przeszłości..., s. 32.

14 A. Stankowski, P. Weiser, Demograficzne skutki Holokaustu, [w:] Następstwa zagłady Żydów. Polska 1944-2010, red. F. Tych, M. Adamczyk-Garbowska, Lublin 2011, s. 38.

15 K. Bojarska, Zagłada..., s. 538-539.
} 
czesnych, a mrocznym spełnieniem możliwości tkwiących w samym sercu projektu nowoczesności"16. Symbolem Holokaustu jest obóz Auschwitz-Birkenau ${ }^{17}$.

Przed II wojną światową teren, który po wojnie stał się województwem rzeszowskim, zamieszkiwało 140119 Żydów (stanowiących 7,8\% ogółu mieszkańców) ${ }^{18}$. W czasie wojny na terenie obecnego Podkarpacia nie było niemieckich obozów zagłady Żydów, ale podobnie jak w całym Generalnym Gubernatorstwie Niemcy zakładali tu obozy pracy (m.in. w Szebniach, gdzie w latach 1943-1944 pracować mogło od 3500 do 5000 Żydów) ${ }^{19}$ i obozy przejściowe: w Pełkiniach koło Jarosławia i Zasławiu koło Sanoka (przez oba te obozy przeszło od 25000 do 28000 Żydów) ${ }^{20}$. Większość Żydów z terenu Rzeszowszczyzny zginęła w latach 1942 i 1943 w ramach Akcji Reinhard w obozie zagłady w Bełżcu ${ }^{21}$. Żydzi ginęli również w masowych egzekucjach przeprowadzanych przez Niemców, w lasach lub na cmentarzach żydowskich ${ }^{22}$. Do wyłapywania Żydów - uciekinierów z gett, transportów do obozów zagłady, przed egzekucjami oraz ukrywających się - Niemcy korzystali również z umiejętności i wiedzy miejscowej ludności, stosując system nagród i zachęt (np. udział w przejmowaniu mienia po mordowanych Żydach) oraz nakazów i kar. Dzięki relacji naocznego świadka wydarzeń najlepiej udokumentowanym przypadkiem udziału miejscowej ludności w Holokauście są zajścia, do których doszło w maju 1942 r. w Gniewczynie Trynieckiej. Grupa Polaków uwięziła, torturowała, okradła, a ostatecznie wydała Niemcom 18 miejscowych Żydów ${ }^{23}$.

Podkarpacie podczas II wojny światowej było terenem nie tylko zagłady Żydów. Doszło tu do masowych mordów przeprowadzanych przez Ukraińską Powstańczą Armię (UPA) na polskiej ludności cywilnej i żołnierzach. Przez NKWD dokonywane były aresztowania członków polskich

16 Z. Bauman, Nowoczesność i Zagłada, Warszawa 1992, za: K. Bojarska, Zagłada..., s. 538-539.

17 S. Kapralski, Od milczenia do "trudnej pamięci”. Państwowe Muzeum Auschwitz-Birkenau i jego rola w dyskursie publicznym, [w:] Następstwa zagłady Żydów..., s. 538.

18 E. Rączy, Zabójstwa dokonane na Żydach w województwie rzeszowskim w latach 1944-1947 w świetle akt organów bezpieczeństwa, [w:] Z dziejów stosunków polsko-żydowskich w XX wieku, red. E. Czop i E. Rączy, Rzeszów 2009, s. 129.

19 E. Rączy, Zagłada Żydów w dystrykcie krakowskim w latach 1939-1945, Rzeszów 2014, s. $175-176$.

20 Tamże, s. 105.

21 Tamże, s. 347-351.

22 E. Rączy, Pomoc Polaków..., s. 40.

23 T. Markiel, A. Skibińska, Zagłada domu Trynczerów, Warszawa 2011. 
organizacji niepodległościowych i ich deportacje w głąb ZSRR. Po wojnie do końca lat czterdziestych przesiedlono stąd przeszło 600000 Ukraińców na Ukrainę i Ziemie Odzyskane (akcja "Wisła”) ${ }^{24}$. Region ten był również terenem walk organizacji antykomunistycznych, m.in. Delegatury Sił Zbrojnych: Wolność i Niezawisłość (WiN) i Narodowe Siły Zbrojne (NSZ).

Zmiany ustrojowe w Polsce po 1989 r. sprawily, że debata publiczna stała się możliwa i otwarta. Jako jeden z ważniejszych tematów społecznych pojawił się Holokaust i stosunki polsko-żydowskie, zwłaszcza w okresie Zagłady. Rozpatrywane były i są przez społeczeństwo, w którym w wyniku Zagłady i powojennych emigracji nie było i w zasadzie nie ma już Żydów, $\mathrm{w}$ związku z tym dotyczą historii i pamięci o Zagładzie oraz stosunku do niej społeczeństwa homogenicznego - jedynie polskiego.

Społeczeństwo to według badań opinii publicznej przeprowadzonych w latach 90. XX w. i na początku XXI w. II wojnę światową zapamiętało jako czas cierpień głównie własnego narodu (50\%), a tylko połowa badanych uznała symbol zagłady Żydów - obóz w Auschwitz-Birkenau - jako miejsce kaźni głównie Żydów. Natomiast relacje polsko-żydowskie w czasie Holokaustu postrzegane są przez Polaków z silną tendencją do przypisywania sobie postaw bohaterskich, za to pamięć o konfliktach, sytuacjach haniebnych lub zbrodniczych jest przez nich usprawiedliwiana lub wypierana ${ }^{25}$.

Według badań socjologa Krzysztofa Malickiego przeprowadzonych wśród studentów Uniwersytetu Rzeszowskiego problematyka Holokaustu jako przedmiot sporów o przeszłość Polski znajduje się na siódmym miejscu najczęściej podejmowanych tematów (po PRL i komunizmie, stanie wojennym, II wojnie światowej rozpatrywanej głównie w kontekście militarnym, transformacji 1989 r. i stosunkach Polski z jej sąsiadami). Holokaust $\mathrm{w}$ tych sporach funkcjonuje $\mathrm{w}$ kontekście antysemityzmu, relacji polsko-żydowskich, postaw Żydów wobec Polski głównie 17 września 1939 r. oraz w okresie PRL-u. Z kolei wśród wydarzeń, które mogą być powodem szczególnej dumy $\mathrm{z}$ historii regionu, badani studenci na szóstym miejscu wymienili pomoc Żydom niesioną przez Polaków (której symbolem jest historia rodziny Ulmów), po powstaniu ruchu ludowego i PSL, walkach partyzanckich w czasie II wojny światowej, przemyśle naftowym, osiągnięciach gospodar-

\footnotetext{
24 K. Malicki, Polacy i ich pamięć przeszłości..., s. 61.

25 A. Sułek, Zwykli Polacy patrza na Żydów. Postawy społeczeństwa polskiego wobec Żydów w świetle badań sondażowych (1967-2008), [w:] Następstwa zagłady Żydów..., s. 881-882.
} 
czo-oświatowych i rabacji galicyjskiej ${ }^{26}$. Rodzina Ulmów zajęła 14 spośród 15 wskazanych przez studentów postaci mogących być przedmiotem dumy dla mieszkańców Podkarpacia ${ }^{27}$. Natomiast wśród lokalnych elit społecznych („,polityczno-samorządowej, medialnej i edukacyjnej” oraz „depozytariuszy i strażników pamięci" ${ }^{28}$ ) najważniejszym aspektem historii regionu w kontekście pamięci zbiorowej i tożsamości, który niesłusznie został zaniedbany i zapomniany, jest Holokaust ${ }^{29}$.

\section{Obchody rocznicowe Holokaustu na Podkarpaciu}

Opierając się na zaprezentowanej typologii szeroko pojmowanej pamięci zbiorowej i sposobach, $\mathrm{w}$ jakich funkcjonuje $\mathrm{w}$ niej Holokaust na poziomie narodowym i lokalnym oraz prezentacji wyników badań socjologicznych, wskazujących, jak w praktyce pamięć o Holokauście funkcjonuje w świadomości wybranych grup społecznych Podkarpacia, dokonano próby analizy sposobów upamiętniania Holokaustu i jego ofiar na podstawie lokalnych obchodów rocznicowych.

Obchody rocznicowe jako wyraz pamięci zbiorowej są doświadczeniem przeszłości, które odbywa się cyklicznie.

\section{Marsz Żywych, Rzeszów}

W 1938 r. w Rzeszowie mieszkało ok. 13000 Żydów, którzy stanowili $30 \%$ populacji miasta ${ }^{30}$. W utworzonym przez Niemców 10 stycznia 1942 r. getcie było przez cały okres jego trwania łącznie ok. 25000 osób, w tym ok. 12000 pochodziło z okolicznych miejscowości ${ }^{31}$. Pierwsze wysiedlenie Żydów z getta przeprowadzone w ramach Akcji Reinhardt odbyło się 7 lipca 1942 r. Niemcy zebrali na terenie cmentarza żydowskiego, z którego

\footnotetext{
26 K. Malicki, Polacy i ich pamięć..., s. 93.

27 Tamże, s. 86.

28 Tamże, s. 149.

29 Tamże, s. 176.

30 W. Wierzbieniec, Żydzi rzeszowscy, [w:] Encyklopedia Rzeszowa, red. Z . Budzyński, Rzeszów 2004, s. 825.

31 Rzeszów, [w:] The Yad Vashem Encyclopedia of the Ghettos during the Holocaust, red. G. Miron, t. II, Jerusalem 2009, s. 675-676.
} 
wcześniej usunęli wszystkie macewy, kilka tysięcy mieszkańców getta, głównie przesiedleńców (kobiety i dzieci) z ziem wcielonych do III Rzeszy i okolicznych miejscowości. Bestialsko znęcali się nad nimi na placu cmentarnym w upale przez kilka godzin, po czym popędzili ich na stację kolejową w Staroniwie. Część Żydów zastrzelili już w drodze na stację. Ze Staroniwy Żydzi zostali wysłani do obozu zagłady w Bełżcu ${ }^{32}$. Tego dnia zginęło w Rzeszowie od 236 do 360 Żydów. Kolejne wysiedlenia do Bełżca odbyły się: 10, 14 i 17 lipca, 7 sierpnia i 15 listopada 1942 r. Wywieziono w ich trakcie na śmierć ok. 16500 Żydów z rzeszowskiego getta ${ }^{33}$.

Pierwszy Marsz Żywych, będący upamiętnieniem krwawych wydarzeń z 7 lipca odbył się w 2002 r. Wspominał go w wywiadzie dla "Gazety Wyborczej" jeden z jego pomysłodawców i organizatorów - rzeszowianin Mirosław Kędzior ${ }^{34}$ : „Była nas zaledwie garstka. Razem z Januszem Korbeckim i kilkoma znajomymi wzięliśmy transparent z gwiazdą Dawida i poszliśmy z placu Ofiar Getta ${ }^{35}$ na dworzec w Staroniwa. Tą samą trasą, którą ponad 20000 rzeszowskich Żydów wyruszyło w podróż do obozów zagłady. W czasie kolejnych marszów odwróciliśmy trasę, żeby symbolicznie odwrócić ten marsz śmierci na marsz żywych"36. Żona jednego ze współ-

32 W. Wierzbieniec, Żydzi rzeszowscy..., s. 826.

33 E. Rączy, Zagłada Żydów w dystrykcie krakowskim..., s. 296-299.

34 Rzeszowianin, opiekun synagogi w Lańcucie z ramienia Fundacji Ochrony Dziedzictwa Żydowskiego. Za coroczną organizację rzeszowskiego Marszu Żywych wraz ze współorganizatorem Januszem Korbeckim w 2012 r. zostali wyróżnieni odznaczeniem „Chroniąc pamięć”, przyznawanym od 1988 r. „Polakom zaangażowanym w zachowanie dziedzictwa żydowskiego w Polsce i dialog polsko-żydowski". Organizatorami projektu są: Ambasada Izraela w Polsce, Fundusz Michaela Traisona dla Polski, Żydowski Instytut Historyczny, Fundacja Ochrony Dziedzictwa Żydowskiego, Muzeum Galicja w Krakowie, Centrum Społeczności Żydowskiej JCC w Krakowie, za: http://www.sztetl.org.pl/en/article/rzeszow/ 19,news/35589,08-07-2012-nagroda-dla-miroslawa-kedziora-i-janusza-korbeckiego-z-rzesz owa/ [01.01.2016].

35 Do 1990 r. plac Zwycięstwa, przed II wojną światową teren starego cmentarza żydowskiego, za: http://podkarpackie.regiopedia.pl/wiki/placem-ofiar-getta-w-rzeszowie-lubila-cho dzic-historia [01.01.2016]. Pierwszymi materialnymi upamiętnieniami ofiar Holokaustu w Rzeszowie były: pomnik odsłonięty w 1947 r. na nowym cmentarzu żydowskim przy ul. Rejtana, którego inicjatorami budowy byli Żydzi uratowani z Holokaustu na terenie Rzeszowszczyzny, pomnik pamięci Żydów Rzeszowa i okolic postawiony w 1995 r. z inicjatywy lokalnych środowisk społecznych w lesie Bór na terenie gminy Głogów Małopolski oraz tablica pamiątkowa wmurowana w ścianę Archiwum Państwowego (dawnej synagogi), sąsiadującego z pl. Ofiar Getta, odsłonięta dzięki staraniom władz miasta i Związku Żydów Rzeszowa w Izraelu w 1998 r. za: W. Wierzbieniec, Miejsca pamięci rzeszowskich Żydów [w:] Encyklopedia Rzeszowa..., s. 318.

36 A. Gorczyca, Trzeba przypomnieć, że żyli tu Żydzi, „Gazeta Wyborcza - Rzeszów” 06.07.2012, s. 2. 
organizatorów, Aneta Kędzior tłumaczy chęć organizacji marszu potrzebami serca i dodaje: „Tu działy się rzeczy, o których młodzi najczęściej nie wiedzą, a starsi nie chcą pamiętać" ${ }^{37}$. Marsz Żywych odbywa się każdego roku 7 lipca, a jego uczestnicy niezmiennie pokonują tę samą trasę: zbierają się na dworcu PKP Staroniwa. Po krótkich przemówieniach z transparentami i flagami Polski i Izraela w ciszy przechodzą ulicami: Pułaskiego, Cieplińskiego, Moniuszki, Matejki, Grunwaldzką, Kopernika aż na pl. Ofiar Getta ${ }^{38}$. Po około godzinie uczestnicy marszu zbierają się przy Kamieniu Pamięci. Tu obywają się wspólne modlitwy, śpiewy - głównie wywodzące się z judaizmu lub wspólne dla obu religii ${ }^{39}$. Przy pomniku składane są kamienie i zapalane znicze ${ }^{40}$. Co roku w marszu bierze udział kilkadziesiąt osób ${ }^{41}$; 2006 r. było to 30-40 osób ${ }^{42}$, a w 2014 r. już 65. Organizatorzy zauważają, że z roku na rok liczba uczestników marszu zwiększa się o dwie, trzy osoby ${ }^{43}$. W marszu uczestniczą nieliczni mieszkańcy Rzeszowa, głównie młodzież ${ }^{44}$, zapraszani są przedstawiciele władz samorządowych i rządowych (marszałek i wojewoda województwa podkarpackiego, prezydent Rzeszowa), przedstawiciele społeczności żydowskiej (Warszawskiej Gminy Wyznaniowej Żydowskiej ${ }^{45}$, Fundacji Ochrony Dziedzictwa Żydowskiego ${ }^{46}$ ). Jednak najliczniejszą grupą biorącą udział w marszu są potomkowie rzeszowskich Żydów wraz ze swoimi czasem kilkupokoleniowymi rodzinami, przyjaciółmi ${ }^{47}$ - ludzie starsi, młodzież i dzieci, przyjezdni głównie z Izraela i Stanów Zjednoczonych ${ }^{48}$. 06.07.2006, s. 3; A. Adamski, Żyjemy, aby pamiętać...; A. Gorczyca, Marsz Pamięci, "Gazeta Wyborcza - Rzeszów" 08.07.2006; A.G., Marsz żywych. Rzeszów wciaż pamięta, "Gazeta Wyborcza - Rzeszów” 07.07.2008, s. 4; K. Staszewska, Marsz upamiętniający likwidację rzeszowskiego getta, "Gazeta Wyborcza - Rzeszów” 07.07.2014, s. 22; A. Adamski, Żyjemy, aby pamiętać...

39 A.G., Marsz żywych. Rzeszów wcią̇̇ pamięta...; A. Adamski, Żyjemy, aby pamiętać...

40 pamiętać...

41 A.G., Marsz żywych. Rzeszów wciąż pamięta...

42 A. Adamski, Żyjemy, aby pamiętać...

43 K. Staszewska, Marsz upamiętniający likwidację rzeszowskiego getta...

44 A.G., Marsz żywych. Rzeszów wciąż pamięta...; A. Adamski, Żyjemy, aby pamiętać...

45 A. Adamski, Żyjemy, aby pamiętać...

46 A. Gorczyca, Micwa się spetniła...

47 A.G., Marsz żywych. Rzeszów wcią̇̇ pamięta...

48 A. Adamski, Żyjemy, aby pamiętać...; A. Gorczyca, Marsz tych, co pamiętaja i chca pamiętać..., Marsz żywych, „Tygodnik Extra”... 
7 lipca 2005 r. dzięki pomysłowi, staraniom i realizacji tych samych rzeszowskich społeczników na placu Ofiar Getta stanął 12-tonowy głaz z tablicą informującą w językach polskim i hebrajskim o znajdującym się w tym miejscu XVI-wiecznym cmentarzu żydowskim, który został zniszczony przez Niemców w czasie II wojny światowej oraz o tym, że w tym samym miejscu latem 1942 r. ${ }^{49}$ Niemcy gromadzili rzeszowskich Żydów przed wywózkami do obozu zagłady w Bełżcu. Po wojnie teren cmentarza przekształcono w park, bez jakiejkolwiek informacji o bogatej i tragicznej historii tego miejsca, jak i o jego znaczeniu $\mathrm{w}$ judaizmie. W uzasadnieniu przyjęcia do realizacji projektu pomnika napisano: „miejsce to jest miejscem niezwykłym na mapie miasta Rzeszowa. Pragnieniem naszym jest postawienie »kamienia-pomnika« przywracającego pamięć wielu pokoleniom Żydów, mieszkańców Rzeszowa, którzy razem z innymi obywatelami miasta współtworzyli historię miasta" 50 . Jeszcze podczas uroczystości odsłonięcia pomnika Mirosław Kędzior $\mathrm{w}$ jednym $\mathrm{z}$ wywiadów wyraził nadzieję, że obelisk i tablica nie zostaną zniszczone, ponieważ „przez kilka ostatnich dni, jakie spędziliśmy przy kamieniu, spotkaliśmy się z najróżniejszymi reakcjami. Były bardzo nieprzychylne, zadziwiła nas reakcja wielu młodych ludzi. Byli zaskoczeni, że tu jest cmentarz. Usprawiedliwiali się, że gdyby o tym wiedzieli, to zachowywaliby się inaczej" ${ }^{51}$. Po jakimś czasie tablica została oblana farbą 52 .

Momentem przełomowym dla organizatorów uroczystości, jak i dla charakteru tych uroczystości był udział $\mathrm{w}$ marszu jednego $\mathrm{z}$ niewielu rzeszowskich Żydów, którzy przeżyli Holokaust, naocznego świadka wysiedlenia Żydów z rzeszowskiego getta do Bełżca - Moshe Ostera ${ }^{53}$. Dworzec Staroniwa był miejscem, w którym Moshe Oster po raz ostatni widział swoich rodziców i rodzeństwo. Miał wtedy 15 lat. Ocalał, ponieważ figurował na liście osób pracujących dla Niemców: „Odśnieżał miasto, pracował w warsztatach Luftwaffe na Staroniwie, w obozie w Pustkowie i Hucie Komorowskiej.

49 A. Gernand, Znak pamięci, "Gazeta Wyborcza - Rzeszów” 30.05.2005, s. 1; A. Adamski, W parku będzie miejsce pamięci, "Nowiny” 07.07.205, s. 6; Upamiętnili rzeszowskich Żydów, „Super Nowości” 08-10.07.2005, s. 6.

50 „Projekt kamienia pamięci na terenie starego cmentarza żydowskiego w Rzeszowie (obecnie plac Ofiar Getta)", ze zbiorów Mirosława Kędziora.

51 A. Gorczyca, Micwa się spetniła...

52 A. Gorczyca, Trzeba przypominać, ̇̇e żyli tu Żydzi, "Gazeta Wyborcza - Rzeszów” 06.07.2012, s. 2.

53 Tamże. 
Zamiast do Bełżca, trafił do Oświęcimia, potem był w Mauthausen, wolność zastała go w obozie w Bergen-Belsen. [...] «Chciałem wrócić, ale w Berlinie spotkałem znajomego z Rzeszowa. On mi powiedział, że nikt nie ocalał, a w Polsce mordują tych Żydów, którzy wracają»"54.

Kolejne marsze $\mathrm{z}$ jego udziałem odbywające się $\mathrm{w}$ atmosferze zadumy i refleksji stawały się wzruszającym rytuałem, w którym ofiara - reprezentująca szerszą społeczność, odpuszcza winy sprawcom i nie domaga się zadośćuczynienia: „Moshe pomimo upływu czasu jest jednym wielkim bólem, zwłaszcza gdy przemierza ulice Rzeszowa. Jego relacje z pobytu i likwidacji getta co chwila przerywa płacz, a głos więźnie w gardle... Wzruszenie udziela się też słuchającym. [...] Ja się pytam dzisiaj Niemców, dlaczego wyście to zrobili? W czym zawadzał wam mój ojciec, który był w Rzeszowie, a wy byliście w Berlinie? I oni tak jak ja, płaczą i nie znajdują odpowiedzi" 55. O upamiętnieniu na cmentarzu żydowskim powiedział: „Ten kamień jest ważniejszy dla was, dla Polaków, nie dla nas, ale cieszę się, że tam jest" 56 . Na zakończenie obchodów, które odbyły się w 2006 r., Mirosław Kędzior przeprosił Moshe Ostera: „Jako Polak i zwykły mieszkaniec Rzeszowa proszę o przebaczenie za krzywdy, bierność i niegodziwości [...]. Około 20 osób ustawia się, by gościowi uścisnąć rękę i powtórzyć słowo: przepraszam" 57 .

Z kolejnymi marszami Oster jako świadek historii stawał się jej bohaterem i symbolem wydarzeń, a jego pamiętanie przeszłości - elementem wiedzy powszechnej o niej. W 2014 r., kiedy nie było go już wśród uczestników obchodów, Mirosław Kędzior rozpoczynając XII Marsz Żywych „wspominał Moshe Ostera i odczytał fragmenty jego książki", po czym powiedział: „Dla nas jest to niczym droga krzyżowa, którą szedł Chrystus. Moshe Oster przebaczył wszystkim, wielokrotnie go o to pytaliśmy - przypomniał Kędzior" ${ }^{58}$. W przekazie medialnym z tych uroczystości zabrakło informacji wyjaśniającej, za co dokładnie organizator przepraszał Moshe Ostera i co gość honorowy wybaczył zgromadzonym. Niemniej jednak wyraźna jest tu tendencja do zrytualizowania obchodów, czyli do nadawania „powtarzalnym ekspresyjno-komunikacyjnym działaniom o charakterze symbolicznym

\footnotetext{
54 A. Gorczyca, Marsz tych, co pamiętaja i chca pamiętać...

55 K. de Tournelle-Krynicka, Moshe poprowadził marsz pamięci, "Super Nowości” 10.07.2006, s. 9.

56 A. Gorczyca, Marsz tych, co pamiętaja i chca pamiętać...

57 A. Adamski, Żyjemy, aby pamiętać...

58 K. Staszewska, Marsz upamiętniający likwidacje rzeszowskiego getta...
} 
charakteru pozaempirycznego" 59 , w tym przypadku dzięki porównaniom do męki Chrystusa i wybaczeniu win - utożsamianego z religią chrześcijańską. W praktyce jest to działanie służące uwierzytelnianiu i uwiarygodnieniu rzeczywistości empirycznej ${ }^{60}$.

Różne były powody, dla których uczestnicy marszu wzięli w nim udział. Żydzi nierzadko pokonywali tysiące kilometrów, ale również wewnętrzne opory swoje i swoich najbliższych po to, by odwiedzić i poznać kraj swoich przodków, a dzięki temu - lepiej zrozumieć swoich najbliższych, ich wybory oraz własną przeszłość, teraźniejszość, siebie samych, czyli własną tożsamość. „Batia Atar, córka Jakova Tuchman Standel, razem z siostrą Ester przyleciała [do Rzeszowa] z Izraela w czwartek wieczorem. [...] - Mój ojciec pochodził z Rzeszowa, ale nigdy po wojnie tu nie był. Nie chciał tu wracać, nie chciał mówić o tym, co przeżył. Opowiadał, jak żyli Żydzi przed wojną, ale nigdy o wojnie. Jestem mu za to wdzięczna, bo wychowaliśmy się bez strachu, bez kompleksu wojny. Zmarł dwa lata temu. Po jego śmierci co roku przyjeżdżamy do Rzeszowa - opowiada" 61 . Inna uczestniczka marszu, Judith Elkin urodzona w Przeworsku, a mieszkająca w Stanach Zjednoczonych, po raz pierwszy przyleciała do Rzeszowa w poszukiwaniu ludzi, którzy pamiętali jej rodziców pochodzących z okolic miasta: „W Przybyszówce spotkałam panią, która tak jak moja mamusia urodziła się w 1914 r. i była jej szkolną koleżanką. Jaka byłam szczęśliwa, gdy dała mi zdjęcie z tego okresu. Są na nim trzy osoby, w tym moja mamusia jako dziewczynka. Odwiedziłam znowu tę rodzinę i dowiedziałam się, że była polska rodzina, która ukrywała Żydów i za to została rozstrzelana" ${ }^{62}$. Od tego momentu co roku bierze udział w marszu, ponieważ dzięki swojemu pochodzeniu czuje się bardzo związana emocjonalnie z tym miastem i Polską: „Ojciec mi zawsze mówił: ty nie zapomnij języka polskiego, a przecież, kiedy uciekliśmy z Polski ja nawet jeszcze nie mówiłam - wspomina" 63 .

Polacy uczestniczący w marszu pytani o powody swej obecności w kilku wypadkach prosili o niepodawanie nazwisk i wyjaśniali: „Pamiętamy i chcemy pamiętać. To żenujące patrzeć na pijaczków siedzących na pl. Ofiar Getta, którzy nie wiedzą (nie chcą wiedzieć), że piją w miejscu kaźni. [...] Marsz Żywych to dla mnie niezwykłe wydarzenie. To zaszczyt, że mogę dać świa-

\footnotetext{
59 S. Kapralski, Rytuat, [w:] Modi memorandi..., s. 444.

60 Tamże.

61 A. Gorczyca, Marsz Pamięci...

62 K. de Tournelle-Krynicka, Moshe poprowadził marsz pamięci...

63 A. Gorczyca, Marsz Pamięci...
} 
dectwo prawdzie. Takie marsze jednoczą ludzi. [...] Jestem Polakiem, ale nie chcę ponosić odpowiedzialności za naszą megalomanię, za nasze narodowe obsesje. I za to, że w naszym kraju co jakiś czas budzą się demony. Dlatego należy przypominać, to co się stało" 64 .

Wśród niektórych Polaków brak pomnika na cmentarzu żydowskim budzi zakłopotanie. Część z nich nie ujawniła dziennikarzom swych nazwisk. Przywoływany w opiniach brak pełnej i rzetelnej wiedzy o lokalnej przeszłości, czego przejawem był przez wiele lat brak upamiętnienia symbolicznego miejsca pamięci o Holokauście rzeszowskich Żydów oraz postawa niektórych mieszkańców Rzeszowa charakteryzująca się lekceważeniem, a nawet bezczeszczeniem miejsc ważnych dla judaizmu, świadczą o tym, że w relacjach polsko-żydowskich nawet na poziomie lokalnym są zagadnienia niezrozumiałe, a niewyjaśniane i przemilczane, mogą rodzić konflikty. Przykład obchodów rzeszowskich potwierdza również szerszy obraz pamięci zbiorowej, że polska pamięć o Holokauście przez lata separowana od pamięci żydowskiej - jest inna.

W myśl teorii, że „upamiętnienie przeszłości i władztwo decydowania o symbolicznym naznaczeniu przestrzeni stanowią nieodłączny atrybut każdej władzy politycznej"65, w przypadku Marszu Żywych widoczne jest subtelne przenikanie państwowej polityki historycznej w oddolne, społeczne upamiętnienie. Egzemplifikuje się tu taka interpretacja przestrzeni symbolicznej zarezerwowanej dla pamięci o zagładzie Żydów, która daje możliwości do podkreślenia równych cierpień Polaków i Żydów i heroicznego udziału Polaków w pomoc niesioną prześladowanym Żydom. W 2009 r. Prezydent Miasta Rzeszowa Tadeusz Ferenc podczas „V Marszu Upamiętniającego Likwidację Getta Żydowskiego w Rzeszowie" życzył jego uczestnikom, by pomimo tego, że słowa wypowiedziane podczas tej uroczystości nie oddadzą "głębi tragedii ofiar Zagłady”, by były „również wymownym świadectwem, że w pożodze ostatniej wojny światowej narody: polski i żydowski stały po tej samej stronie - ofiar" ${ }^{\prime 66}$. W podobnym piśmie wystosowanym w 2013 r. podkreślił, że: „W przypadku Rzeszowa z przeszło 25000 [Żydów] ocalało nie więcej niż 200 osób ukrytych m.in. przez ludność

\footnotetext{
64 A. Adamski, Żyjemy, aby pamiętać...

65 K. Malicki, Upamiętnienie przeszłości jako źródło konfliktów w przestrzeni symbolicznej regionu podkarpackiego, [w:] Pamięć zbiorowa jako czynnik integracji i źródto konfliktów, red. A. Szpociński, Warszawa 2009, s. 49.

66 Pismo Prezydenta miasta Rzeszowa do Mirosława Kędziora i Janusza Korbeckiego, Rzeszów 05.07.2009, ze zbiorów Mirosława Kędziora.
} 
polską" 67, a dwa lata później zaznaczył, że: „W dobie relatywizowania odpowiedzialności za Holokaust ciągle warto przypominać, że to Niemcy, a nie Polacy, byli jego sprawcami" 68 . Wystąpienia są przykładami, jak silnie politycznie nacechowana jest pamięć o Holokauście, gdy w miejscu symbolizującym śmierć Żydów - znacznej części mieszkańców miasta jego władze podkreślają jedność ofiary Polaków i Żydów oraz heroizm poświęcenia Polaków dla ratowania Żydów.

\section{Dni Pamięci o Żydowskiej Społeczności Rymanowa, Rymanów}

Rymanów przed II wojną światową był ważnym ośrodkiem chasydyzmu. Tu swoją siedzibę miała dynastia cadyków założona przez Menachema Mendla (1755-1815). Według tradycji słynął (nie tylko wśród społeczności żydowskiej) z daru jasnowidzenia i leczenia chorób. Jego ohel znajdujący się na cmentarzu żydowskim w Rymanowie ${ }^{69}$ jest do dziś celem pielgrzymek chasydów z całego świata. Według spisu powszechnego w 1921 r. w Rymanowie mieszkało 3546 osób, w tym 1412 Żydów, stanowiących przeszło 39\% mieszkańców miasta ${ }^{70}$. Niemcy utworzyli getto w $1941 \mathrm{r} .{ }^{71}$, a jego likwidację przeprowadzili 13 sierpnia 1942 r. Żydów wypędzili z domów na rynek. Tam przeprowadzili selekcję, dzieląc ich na trzy grupy. Mężczyzn zatrudnili do prac drogowych na terenie Rymanowa, a następnie wysłali do obozu pracy w Płaszowie. Około 500 osób popędzili na stację kolejową do Wróblika Szlacheckiego, skąd wywieziono ich do obozu zagłady w Bełżcu. Pozostałych mieszkańców getta - kobiety, starców i dzieci - Niemcy wywieźli do lasu

67 Pismo Prezydenta miasta Rzeszowa do Janusza Korbeckiego, Rzeszów 07.07.2013, ze zbiorów Mirosława Kędziora. Krzysztof Kaczmarski podaje, że Holokaust przeżyło 700-800 rzeszowskich Żydów, ok. $100 \mathrm{w}$ niemieckich obozach koncentracyjnych, pozostali na ternie Związku Radzieckiego, zob. K. Kaczmarski, Pogrom, którego nie było. Rzeszów, 11-12 czerwca 1945 r. Fakty, hipotezy, dokumenty, Rzeszów 2008, s. 15. W sprzeczności do tych danych stoją ustalenia Elżbiety Rączy, według której ocalało 466 Żydów rzeszowskich Żydów, a 309 dzięki ukrywaniu ich przez Polaków, zob. E. Rączy, Pomoc Polaków..., s. 119.

68 Pismo Prezydenta miasta Rzeszowa do Mirosława Kędziora i Janusza Korbeckiego, Rzeszów 05.07.2015, ze zbiorów Mirosława Kędziora.

69 J. Doktór, Menachem Mendel z Rymanowa, [w:] Polski słownik judaistyczny. Dzieje, kultura, religia, ludzie, red. Z. Borzymińska, R. Żebrowski, t. 2, Warszawa 2003, s. 130.

70 B. Wasiutyński, Ludność żydowska w Polsce w wiekach XIX i XX. Studjum statystyczne, Warszawa 1930, s. 118.

71 Rymanów, [w:] The Yad Vashem Encyclopedia of the Ghettos..., t. II, s. 673. 
Błudna koło Tylawy i tam zastrzelili. Osoby niepełnosprawne i niedołężne zginęły w ten sam sposób na miejscowym cmentarzu żydowskim. Tego dnia zabito ogółem 100 osób ${ }^{72}$.

Dni Pamięci o Społeczności Żydowskiej Rymanowa obchodzone są od 2008 r., a ich instytucjonalnym organizatorem jest Stowarzyszenie „Spotkanie Rymanów" prowadzone przez mieszkających na Śląsku Michała i Adama Lorenców, przy współudziale głównie: Fundacji Ochrony Dziedzictwa Żydowskiego, Krośnieńskiego Przedsiębiorstwa Budowlanego w Krośnie SA i Restauracji i Hotelu Jaś Wędrowniczek ${ }^{73}$. O spontanicznym, społecznym charakterze upamiętnienia świadczy wypowiedź jednego z organizatorów, Michała Lorenca ${ }^{74}$ podczas pierwszej uroczystości: „Nie wiem, czy kolejne [obchody] odbędą się za rok czy za dwa, bo nie wiem, czy ludzie, którzy przyjechali teraz, będą mogli tu jeszcze kiedyś przyjechać" 75 . Z powyższej wypowiedzi jasno też wynika, że kluczowymi uczestnikami obchodów są goście z zagranicy. Niemniej jednak powodem, dla którego corocznie odbywają się Dni Pamięci jest chęć „przypomnienia i pokazania mieszkańcom Rymanowa i tym, którzy chcą uczestniczyć w tym spotkaniu, tę część historii miasta, która minęła bezpowrotnie" 76 , po to, by lepiej się poznać i zrozumieć $^{77}$. W ostatniej wypowiedzi, wartą podkreślenia jest uwaga, że uroczystości przeznaczone są dla wszystkich tych, którzy chcą w nich uczestniczyć. A są nimi przede wszystkim potomkowie rymanowskich Żydów z Europy (Niemiec, Węgier, Wielkiej Brytanii), Izraela i Stanów Zjednoczonych ${ }^{78}$. Zaproszenia są kierowane również do władz samorządowych, władz wojewódzkich, przedstawicieli polskiego MSZ, ambasadora Izraela i miejscowego

72 E. Rączy, Zagłada Żydów w dystrykcie krakowskim..., s. 319.

73 List do programu „Dni Pamięci o żydowskiej społeczności Rymanowa”, 12-13.08.2008, 12-13.08.2009, 11-13.08.2011, 08-10.08.2012, 15-18.08.2014, ze zbiorów M. Lorenca.

74 Wraz z bratem Adamem założyli Stowarzyszenie „Spotkanie Rymanów” - projekt publiczny przeznaczony dla mieszkańców Rymanowa, by promować tradycję wielokulturowego Rymanowa, „odkrywać przeszłość oraz przywracać pamięci o rymanowskich Żydach", za: http://www.sztetl.org.pl/en/article/rymanow/20,culture-social-and-education al-projects/22154,michal-lorenc-stowarzyszenie-spotkanie-rymanow-/ [01.01.2016].

75 A. Gorczyca, Uczcza pamięć rymanowskich Żydów, „Gazeta Wyborcza - Rzeszów” 12.08.2008, s. 1.

76 A. Gorczyca, Przyjechali na szabat do Rymanowa, "Gazeta Wyborcza - Rzeszów” 12.08.2010, s. 4.

77 List do programu „Dni Pamięci o żydowskiej społeczności Rymanowa”, 12-13.08.2008, ze zbiorów M. Lorenca.

78 A. Gorczyca, W Rymanowie: Radość wesela i zaduma wspomnień, „Gazeta Wyborcza - Rzeszów" 11.08.2011, s. 1. 
proboszcza $^{79}$. W uroczystościach licznie biorą również udział mieszkańcy Rymanowa i goście z Polski zainteresowani kulturą żydowską ${ }^{80}$ - to czasem nawet kilkaset osób ${ }^{81}$.

Główne uroczystości rozpoczynają się na miejscowym cmentarzu żydowskim modlitwą ekumeniczną prowadzoną przez rabina i proboszcza rymanowskiej parafii. Po niej odbywa się Marsz Pamięci. Zaczyna się na rymanowskim rynku, a kończy na stacji kolejowej we Wróbliku. To marsz upamiętniający ostatni pochód rymanowskich Żydów na stację kolejowa, z której w sierpniu 1942 r. zostali wywiezieni do obozu zagłady w Bełżcu.

Każdemu upamiętnieniu rokrocznie towarzyszy temat przewodni, motyw pochodzący z kultury i historii Żydów, który tematycznie rzutuje na charakter uroczystości towarzyszących. To sami uczestnicy nadali charakter pierwszemu upamiętnieniu - potraktowali je jak symboliczny pogrzeb po 66 latach, którego zamordowani rymanowscy Żydzi nie mieli. Wtedy na cmentarzu żydowskim modlił się wraz z księdzem katolickim Mieczysławem Szostakiem, Menachem Abraham Reich - potomek w ósmym pokoleniu cadyka Menachema Mendla ${ }^{82}$. Kolejne uroczystości poświęcone były Sprawiedliwym wśród Narodów Świata, a zwłaszcza ks. Janowi Zawrzyckiemu, który w czasie II wojny światowej w Rymanowie ratował dzieci żydowskie $(2009 \text { r. })^{83}$. Pokłosiem tych obchodów było w 2011 r. odsłonięcie tablicy pamiątkowej na cmentarzu komunalnym w Rymanowie, upamiętniającej Polaków ratujących Żydów ${ }^{84}$. Inne uroczystości poświęcone były najważniejszemu świętu żydowskiemu - szabatowi (2010 r.) ${ }^{85}$, tradycyjnej chasydzkiej uroczystości weselnej $(2011 \text { r. })^{86}$, czy też żydowskiemu cmentarzowi - domowi życia - Bet Chaim - House of Life $(2015 \text { r. })^{87}$.

79 List do programu „Dni Pamięci o żydowskiej społeczności Rymanowa”, 12-13.08.2008, ze zbiorów M. Lorenca.

80 A. Gorczyca, Dni pamięci w Rymanowie, "Gazeta Wyborcza - Rzeszów” 13.08.2015, s. 2.

81 http://www.nowiny24.pl/wiadomosci/krosno/art/6052665,rozpoczely-sie-dni-pamieci-ozydowskiej-spolecznosci-rymanowa,id,t.html [stan na 31.12.2015].

82 A. Gorczyca, Uczcza pamięć rymanowskich Żydów...

83 Tejże, Rymanów uczci Żydów i Polków, którzy im pomagali, "Gazeta Wyborcza - Rzeszów” 10.08.2009, s. 4.

84 List do programu „Dni Pamięci o żydowskiej społeczności Rymanowa”, 11-13.08.2011, ze zbiorów M. Lorenca.

85 A. Gorczyca, Przyjechali na szabat do Rymanowa...

86 Tejże, W Rymanowie: radość wesela $i$ zaduma wspomnień...

87 Tejże, Dni pamięci w Rymanowie... 
Dni Pamięci były nie tylko wspominaniem rymanowskich Żydów, ale również okazją do zaprezentowania kultury i tradycji żydowskiej. W czasie obchodów prezentowane były m.in. filmy („Gra w chowanego - Wiara i tolerancja po Holokauście”, reż. M. Daum, 2008 r. ${ }^{88, ~ " M i a s t e c z k o ~ R y m a n o ́ w ~}$ - Main Sztetełe Rymanów", reż. A. Potocki, 2011 r. ${ }^{89}$ ). Prowadzono warsztaty odczytywania symboli macew (2009 r. $)^{90}$, koncerty muzyki klezmerskiej (2009 r.), spektakle teatralno-muzyczne, warsztaty języka jidysz i intonacji nigunów (2010 r. $)^{91}$, spacery po mieście śladami rymanowskich Żydów, pokazy tradycyjnych tańców, modlitw i śpiewu, degustacje potraw kuchni żydowskiej ${ }^{92}$, zorganizowano wystawę fotografii archiwalnej ${ }^{93}$.

Obchody Dni Pamięci o Społeczności Żydowskiej Rymanowa nie są wolne od trudnych tematów i negatywnych emocji, które wywołują w uczestnikach uroczystości. Gdy po raz pierwszy Żydzi przyjechali do Rymanowa i oni, i mieszkańcy miasteczka mieli sporo obaw: „w pamięci tych, którzy ocaleli pozostały złe wspomnienia: okupacji i antysemityzmu, jakiego doświadczyli przed wojną. Mieszkańcy Rymanowa obawiali się tego, że dawni właściciele kamienic zaczną się upominać o swoją własność". Niemniej jednak spotkanie i wspólny Marsz Pamięci zniwelowały obawy obu stron ${ }^{94}$.

\section{Międzynarodowy Dzień Pamięci o Ofiarach Holokaustu}

To święto ustanowione w 2005 r. przez Zgromadzenie Ogólne ONZ, by uczcić pamięć Żydów, zamordowanych w czasie II wojny światowej przez nazistowskie Niemcy. Obchodzone jest corocznie 27 stycznia - w rocznicę wyzwolenia niemieckiego obozu koncentracyjnego Auschwitz-Birkenau w 1945 r.

Międzynarodowy Dzień Pamięci o Ofiarach Holokaustu obchodzony jest na Podkarpaciu od 2009 r.

Pierwsze uroczystości odbyły się w Rzeszowie. Jego organizatorami były wówczas Uniwersytet Rzeszowski, a dokładnie Pracownia Historii i Kultury

\footnotetext{
88 A. Gorczyca, Rymanów uczci Żydów i Polków, którzy im pomagali...

89 Tejże, W Rymanowie: radość wesela i zaduma wspomnień...

90 Tejże, Rymanów uczci Żydów i Polków, którzy im pomagali...

91 Tejże, Przyjechali na szabat do Rymanowa...

92 http://www.nowiny24.pl/wiadomosci/krosno/art/6125437,do-rymanowa-zjezdzaja-poto mkowie-rymanowskich-zydow,id,t.html [31.12.2015].

93 A. Gorczyca, Dni Pamięci w Rymanowie...

94 Tejże, Rymanów uczci Żydów i Polaków, którzy im pomagali...
} 
Żydów Instytutu Historii, Klasztor Dominikanów oraz Instytut Pamięci Narodowej Oddział Rzeszowie ${ }^{95}$.

Profesor Wacław Wierzbieniec, współorganizator obchodów z ramienia Uniwersytetu Rzeszowskiego, kierownik tamtejszej Pracowni Historii i Kultury Żydów wyjaśnia, że jest wiele powodów, by pamiętać o Holokauście: „Wiedzę o zagładzie Żydów należy traktować jako ostrzeżenie przed ponownym niebezpieczeństwem. Poznanie Holokaustu, to poznanie mechanizmów zła, które - chodź na mniejszą skalę - ciągle pojawia się na świecie, np. w byłej Jugosławii czy Afryce. Wiedza o Holokauście jest naszym moralnym obowiązkiem wobec tych, którzy współtworzyli z Polakami małe ojczyzny, choćby takie właśnie jak Rzeszów. W sensie intelektualnym pozwala zrozumieć, jak wielki wkład wnieśli Żydzi w naszą tożsamość kulturową, jak wiele straciliśmy, gdy ich zabrakło" 96 oraz że szczególnie na Podkarpaciu powinno się mówić o zagładzie Żydów, ponieważ przed II wojną światową Żydzi stanowili tu [na Podkarpaciu] blisko połowę lokalnej społeczności ${ }^{97}$.

Uroczystości rozpoczęto „uczczeniem ofiar Holokaustu (pochowanych w zbiorowych mogiłach) ${ }^{98}$ " na nowym cmentarzu żydowskim przy al. Rejtana, a zakończono nabożeństwem w kościele oo. Dominikanów, podczas którego odczytano nazwiska Polaków z Rzeszowszczyzny, którzy „zginęli niosąc pomoc Żydom, i Żydów, którzy ponieśli śmierć z nimi" ${ }^{99}$. Ważnym elementem obchodów była sesja naukowa poświęcona osobom „Doświadczonym Holocaustem". Wzięli w niej udział świadkowie Holokaustu, potomkowie Polaków, którzy w czasie II wojny światowej ratowali Żydów (odznaczeni medalem "Sprawiedliwych wśród Narodów Świata”) oraz ksiądz katolicki pochodzenia żydowskiego, którego rodzina zginęła w Holokauście ${ }^{100}$. Obchodom towarzyszyła wystawa, odsłonięta w holu uniwersyteckim, po-

95 K. Thomas, Pracownia Historii i Kultury Żydów Instytutu Historii Uniwersytetu Rzeszowskiego, [w:] Studia żydowskie w Polsce - przeszłość, stan obecny, perspektywy. Studium selektywne, red. S. Gąsiorowski, Kraków 2014, s. 243.

96 Agata Kulczycka, Świadek opowiada o Holocauście, „Gazeta Wyborcza - Rzeszów” 21.01.2009, s. 2.

97 http://www.polskatimes.pl/artykul/81187,obchody-dnia-pamieci-ofiar-holocaustu-w-pol sce-i-na-swiecie,id,t.html [28.12.2015].

98 prezentacja-programu-obchodow-w-rzeszowie-miedzynarodowego-dnia-pamieci-o-ofiara [28.12.2015].

99 A. Kulczycka, Ożywić pamięć o ofiarach Holocaustu, „Gazeta Wyborcza - Rzeszów” 28.01. 2009, s. 1.

100 Tamże. 
święcona rodzinie rzeszowskiego filantropa Adolfa Tennenbauma oraz recital pieśni w jidysz ${ }^{101}$.

Elementy upamiętnienia o charakterze religijnym - poranna modlitwa ekumeniczna (Kadisz i „Wieczne odpoczywanie”) prowadzona przez rabina i księdza katolickiego na cmentarzu żydowskim przy al. Rejtana oraz wieczorne nabożeństwo w kościele oo. Dominikanów, a w latach 2013-2015 w kościele Farnym p. w. św. Wojciecha i św. Stanisława stanowią tradycyjną częścią obchodów. Regułą przyjętą w kolejnych latach było również odczytywanie imion i nazwisk bądź samych imion, a czasami tylko informacji o liczbie osób: „Polaków z Rzeszowszczyzny, zamordowanych za pomoc niesioną Żydom podczas okupacji niemieckiej, i Żydów, którzy ponieśli śmierć wraz z nimi" ${ }^{102}$. Nazwiska Polaków odczytywał gość specjalny, zazwyczaj Lucia Retman wraz z innymi świadkami Holokaustu ${ }^{103}$, zaś nazwiska Żydów - przedstawiciel władz samorządowych ${ }^{104}$. Wśród wymienianych wtedy miejscowości Podkarpacia zawsze znajdowała się Gniewczyna Łańcucka, a proboszcz tamtejszej parafii brał udział w corocznym uroczystym nabożeństwie, co zgodnie z opinią prof. Wierzbieńca miało „ważne, symboliczne znaczenie, bo według informacji, które zostały ostatnio dość szeroko rozpowszechnione, w Gniewczynie Łańcuckiej w czasie II wojny światowej udział w eksterminacji miejscowej ludności żydowskiej wzięli mieszkańcy tej miejscowości" 105 .

Stałym elementem obchodów były również sesje, wykłady, wystawy, debaty, odczyty, prezentacje filmów, promocje książek przybliżające wspominane wydarzenia lub ich aspekty w sposób naukowy lub częściej popularnonaukowy ${ }^{106}$.

Drugim obchodom Międzynarodowego Dnia Pamięci o Ofiarach Holokaustu towarzyszyła uroczystość odznaczenia Polaków, którzy ratowali Żydów w czasie Zagłady - „Przywracanie pamięci o Polakach ratujących Ży-

101 prezentacja-programu-obchodow-w-rzeszowie-miedzynarodowego-dnia-pamieci-o-ofiara [28.12.2015].

102 K. Thomas, Pracownia Historii i Kultury Żydów..., s. 243.

103 http://www.pwste.edu.pl/aktualnosci/zycie-uczelni/1813-vi-obchody-miedzynarodowego -dnia-pamieci-o-ofiarach-holokaustu-w-rzeszowie, http://www.pwste.edu.pl/aktualnosci/ zycie-uczelni / 2889-vii-obchody-miedzynarodowego-dnia-pamieci-o-ofiarach-holokaustuw-rzeszowie [30.12.2015]; A. Kulczycka, Zaczynamy od Kadiszu..., „Gazeta Wyborcza - Rzeszów" 25.01.2011, s. 2.

104 L. Szura, Srebrna łyżeczka jak metryka, "Gazeta Wyborcza - Rzeszów” 28.01.2010, s. 2.

105 A. Kulczycka, Zaczynamy od Kadiszu...

106 Lucy, Pamiętamy o ofiarach Holocaustu, "Gazeta Wyborcza - Rzeszów” 26.01.2010, s. 2. 
dów w czasie Zagłady", która odbyła się 9 lutego 2010 r. w Urzędzie Marszałkowskim Województwa Podkarpackiego. Jej organizatorami były: Kancelaria Prezydenta RP, Biuro Inicjatyw Społecznych, Biuro Kadr i Odznaczeń we współpracy z IPN Oddziałem w Rzeszowie oraz Urząd Marszałkowski Województwa Podkarpackiego. Odznaczenia nadane przez Prezydenta RP Lecha Kaczyńskiego wręczyła Maria Kaczyńska oraz Sekretarz Stanu w Kancelarii Prezydenta RP Ewa Junczyk-Ziomecka. W uroczystości udział wzięli: marszałek województwa podkarpackiego, dyrektor IPN w Rzeszowie i osoby odznaczane wraz z rodzinami. Po uroczystości goście zostali zaproszeni m.in. na prezentację multimedialną o pomocy Polaków dla ludności żydowskiej na Rzeszowszczyźnie oraz audiowizualną prezentację muzeum im. Rodziny Ulmów w Markowej ${ }^{107}$. Uroczystość ta została upamiętniona wzmianką zamieszoną na pomniku poświęconym ofiarom katastrofy smoleńskiej, pochodzącym z Podkarpacia oraz parze prezydenckiej Lechowi i Marii Kaczyńskim i ostatniemu Prezydentowi RP na uchodźstwie Ryszardowi Kaczorowskiemu. Pomnik został odsłonięty w grudniu 2015 r. obok Urzędu Marszałkowskiego w Rzeszowie ${ }^{108}$.

Obchody Międzynarodowego Dnia Pamięci o Ofiarach Holokaustu w 2010 i 2011 r. miały bogatszy, kilkudniowy program wydarzeń (2010 r.), przygotowywany we współpracy z klasztorem Ojców Dominikanów w Rzeszowie i Podkarpackim Centrum Edukacji Nauczycieli109. Współorganizatorami obchodów w 2011 r. byli: Polskie Towarzystwo Historyczne Odział w Rzeszowie i Regionalne Stowarzyszenie Pamięci Historycznej „ŚLAD”110. "Motywami przewodnimi" uroczystości były postaci Ireny Sendlerowej (2010 r.) i Jana Karskiego (2011 r.) ${ }^{111}$ - bohaterów z czasów Holokaustu, uhonorowanych tytułem „Sprawiedliwi wśród Narodów Świata”, którzy $\mathrm{w}$ pamięci zbiorowej funkcjonują jako wzory postaw Polaków wobec

107 http://ipn.gov.pl/aktualnosci/2010/centrala/uroczystosc-odznaczenia-polakow,-ktorzyratowali-zydow-w-czasie-zaglady-rzeszo [28.12.2015].

108 http://www.nowiny24.pl/wiadomosci/rzeszow/art/9171298,w-niedziele-odslonieciepomnika-ofiar-katastrofy-smolenskiej-w-rzeszowie-zdjecia,id,t.html [01.01.2016].

109 http://rzeszow.dlastudenta.pl/sztuka/artykul/Dzien_Pamieci_o_Ofiarach_Holocaustu_w_ Rzeszowie,47439.html [28.12.2015].

110 http://www.fzp.net.pl/zaproszenia/obchody-miedzynarodowego-dnia-pamieci-o-ofiarach -holocaustu-w-rzeszowie [28.12.2015].

111 W wywiadzie udzielonym dla "Gazety Wyborczej" tuż przed uroczystościami prof. Wacław Wierzbieniec powiedział: „w tym [roku] najbardziej eksponowana będzie postać wybitnego Polaka prof. Jana Karskiego, który swoją postawą na arenie międzynarodowej w sposób jednoznaczny ukazał, że w znacznej części społeczeństwu polskiemu zależało na ratowaniu Żydów"; A. Kulczycka, Zaczynamy od Kadiszu... 
Żydów ${ }^{112}$. Gośćmi honorowymi uroczystości byli Irena Ficowska, jedno z dzieci uratowanych przez Sendlerową i Ewa Wierzyńska koordynatorka programu "Jan Karski - niedokończona misja” w Muzeum Historii Polski.

Przykładem poprzednich uroczystości odbyły się również spotkania ze świadkami historii, ocalonymi z Zagłady, którzy doświadczeniami wojennymi podzielili się ze studentami Uniwersytetu Rzeszowskiego. Jedną z nich (gościem honorowym obchodów) była urodzona w Lubaczowie, a mieszkająca w Izraelu Lucia Retman ${ }^{113}$. W 2013 r. Retman powiedziała: „za każdym razem, kiedy jestem w Polsce, staram się uczcić pamięć Zofii Pomorskiej. Dzięki jej bohaterstwu przeżyłam wojnę"114 - dawanie świadectwa heroizmowi osoby, która uratowała jej życie, to główny powód udziału Retman w podkarpackich obchodach. Przywoływanie wspomnień o odwadze, dobroci i zaradności Zofii Pomorskiej, pośmiertnie odznaczonej medalem „Sprawiedliwy wśród Narodów Świata" jest głównym motywem organizowanych spotkań, debat, a ona sama jest bohaterką już nie tylko Luci Retman, ale również staje się wzorem postaw moralnych i jako "Sprawiedliwa" - symbolem swoich czasów dla osób uczestniczących w spotkaniach z Retman. Retman jest stałym gościem honorowym wszystkich kolejnych uroczystości. Częstymi uczestnikami obchodów, świadkami Holokaustu, którzy również dzielą się swoimi wspomnieniami z czasu wojny są: Miki Basch (Izrael), Judit Elkin (USA), Roman Kessler (Izrael) i Ora Regev (Izrael) ${ }^{115}$. W obchodach biorą również udział potomkowie Żydów, którzy przeżyli Holokaust. Jan Gebert: „Żydów w Polsce zostało bardzo niewielu, zbyt niewielu, aby podtrzymać pamięć o przodkach. Dlatego czuję się zobowiązany, aby wspierać takie wspaniałe inicjatywy jak profesora Wierzbieńca. Bo dzięki takim ludziom jak profesor podtrzymywana jest pamięć o Żydach, którzy współtworzyli przez niemal tysiąc lat historię Polski" ${ }^{\prime 16}$.

Od 2012 r. istotna część obchodów Dnia Pamięci o Ofiarach Holokaustu na Podkarpaciu przeniosła się do Jarosławia, a ich głównym organizatorem został prof. Wacław Wierzbieniec, który w latach 2011-2015 był rektorem

112 http://www.jankarski.org/program/news/n/irena-sendlerowa-zostala-upamietniona-wwarszawie/, http://wyborcza.pl/1,91446,16918525,Jan_Karski__symbol_pamieci_i_odpow iedzialnosci.html [30.12.2015].

113 L. Szura, Srebrna łyżeczka jak metryka...

114 http://www.nowiny24.pl/wiadomosci/jaroslaw/art/6180621,w-jaroslawiu-uczcili-ofiaryholokaustu,id,t.html [30.12.2015].

115 http://www.sztetl.org.pl/pl/cms/aktualnosci/3114,ii-obchody-miedzynarodowego-dniapamieci-o-ofiarach-holokaustu-w-jaroslawiu/ [30.12.2015].

116 Wywiad udzielony w Jarosławiu 28.01.2016. 
tamtejszej Państwowej Wyższej Szkoły Techniczno-Ekonomicznej (PWSTE). Uroczystości współorganizowali również: Ośrodek Kultury i Formacji Chrześcijańskiej w Jarosławiu, burmistrz Jarosławia i Fundacja Ochrony Dziedzictwa Żydowskiego ${ }^{117}$.

Wzorem poprzednich lat odbyło się nabożeństwo w intencji „Polaków $\mathrm{z}$ Podkarpacia zamordowanych za pomoc niesioną Żydom oraz w intencji Żydów, którzy ponieśli śmierć na tym terenie"118 w kościele Świętych Mikołaja i Stanisława Biskupa w Jarosławiu. Tu również przez Żydów, gości honorowych uroczystości i burmistrza miasta odczytana została lista ofiar Polaków zamordowanych za niesienie pomocy Żydom oraz Żydów, którzy z nimi zginęli ${ }^{119}$. Intencja nabożeństwa wyraźnie sugeruje odmienne rozłożenie akcentów pomiędzy modlitwę za Polaków - męczenników, którzy złożyli największą ofiarę za ratowanie Żydów i Żydów, którzy zginęli na tym terenie, bez uwzględnienia Żydów, którzy z tego terenu zginęli w obozach zagłady znajdujących się poza obszarem obecnego Podkarpacia lub Żydów, którzy $\mathrm{w}$ większości zginęli $\mathrm{w}$ innych okolicznościach niż podczas pomocy niesionej przez Polaków. Organizatorzy dzięki temu jednoznacznie przenoszą akcent na szerszy zasięg zjawiska eksterminacji Żydów, które dotknęło również część społeczeństwa polskiego.

Momentem kulminacyjnym obchodów było przejście pod mur rozstrzeliwań jarosławskiego Opactwa Sióstr Benedyktynek, który symbolizuje miejsce masowego rozstrzelania Polaków i Żydów, gdzie upamiętniono ofiary Holokaustu z Jarosławia.

Uczestnikami części oficjalnej obchodów byli głównie przedstawiciele lokalnych elit, duchowni i lokalni reprezentanci świata nauki i kultury: prorektorzy uczelni PWSTE, burmistrz miasta Jarosławia i władze powiatu, parlamentarzyści, przeor Klasztoru Dominikanów, proboszcz cerkwi Grekokatolickiej Przemienienia Pańskiego, służby mundurowe, uczniowie i studenci lokalnych uczelni, zaproszeni goście z kraju i zagranicy ${ }^{120}$.

Jarosławskim obchodom towarzyszyły wzorem obchodów rzeszowskich wydarzenia koncentrujące się głównie wokół tematu Sprawiedliwych wśród Narodów Świata, m.in. wykłady (E. Rączy, Motywy podjęcia decyzji przez Po-

\footnotetext{
117 http://www.nowiny24.pl/wiadomosci/jaroslaw/art/6180621,w-jaroslawiu-uczcili-ofiaryholokaustu,id,t.html [30.12.2015].

118 http://www.niedziela.pl/artykul/110588/nd/Miedzynarodowy-Dzien-Pamieci-o-Ofiarach [30.12.2015].

119 Tamże.

120 http://www.pwste.edu.pl/aktualnosci/zycie-uczelni/2891-iv-obchody-miedzynarodowego -dnia-pamieci-o-ofiarach-holokaustu-w-jaroslawiu [30.12.2015].
} 
laków ratujących Żydów 2012 r., E. Rączy, Polacy ratujący Żydów w Krośnie 2015 r. ${ }^{121}$ ), debaty („Stosunki polsko-żydowskie z perspektywy Uratowanych i Ratujących w czasie Holokaustu" 2014 r. ${ }^{122}$ ), wystawy („Samarytanie z Markowej. Ulmowie - Polacy zamordowani przez Niemców za uratowanie ośmiorga Żydów” Mateusza Szpytmy ${ }^{123}$, „Sprawiedliwi wśród Narodów Świata. Pomoc Polaków dla ludności żydowskiej w Małopolsce w latach 1939-1945" IPN 124). Próbą podjęcia dyskusji na temat szeregu odmiennych postaw, jakie również prezentowali Polacy wobec ginących w Holokauście Żydów (od bierności, po czynny w nim udział) była akademicka debata nt. Ocena postaw Polaków wobec Żydów w czasie niemieckiej okupacji, poprowadzona przez prof. Elżbietę Rączy z Uniwersytetu Rzeszowskiego i Instytutu Pamięci Narodowej Oddział w Rzeszowie oraz Jakuba Izdebskiego z Instytutu Pamięci Narodowej Oddział w Rzeszowie w Centrum Dialogu Między Religiami i Narodami Państwowej Wyższej Szkoły Techniczno-Ekonomicznej im. ks. Bronisława Markiewicza w Jarosławiu w 2015 r. ${ }^{125}$

Elementem obchodów popularyzującym kulturę Żydów w Polsce były koncerty pieśni chasydzkich (2014 r. $\left.{ }^{126}\right)$, muzyki Władysława Szpilmana (2014 r. ${ }^{127)}$, degustacje kuchni żydowskiej czy symboliczne obchodzony szabat (w latach 2012, 2014 ${ }^{128}$ ).

O rosnącym zainteresowaniu społecznym tematyką Holokaustu świadczy przystąpienie do udziału w obchodach Międzynarodowego Dnia Pamięci o Ofiarach Holokaustu innych miejscowości z regionu Podkarpacia: Lubaczowa (2014 r.), Krosna, Kolbuszowej (2015 r.). Wszędzie tam scenariusze obchodów są podobne do rzeszowskich i jarosławskich Dni Pamięci o Holokauście. Ofiary czczone są na cmentarzach żydowskich, organizowane są spotkania ze świadkami Holokaustu, często pochodzącymi z danej miejsco-

\footnotetext{
121 A. Gorczyca, Pamięci ofiar Holocaustu, „Gazeta Wyborcza - Rzeszów” 27.01.2015, s. 3.

122 M. Bojarska, Międzynarodowy Dzień Pamięci o Ofiarach Holokaustu...

123 ASK, Rzeszów pamięta o ofiarach Holocaustu, "Gazeta Wyborcza - Rzeszów” 28.01.2011, s. 2.

124 http://ekai.pl/diecezje/przemyska/x86070/jaroslaw-obchody-miedzynarodowego-dniapamieci-o-ofiarach-holokaustu/ [30.12.2015].

125 http://ekai.pl/diecezje/przemyska/x86070/jaroslaw-obchody-miedzynarodowego-dniapamieci-o-ofiarach-holokaustu/ [30.12.2015].

126 M. Bojarska, Międzynarodowy Dzień Pamięci o Ofiarach Holokaustu, „Niedziela” 16.02.2014, s. 5.

127 http://www.pwste.edu.pl/aktualnosci/zycie-uczelni/1813-vi-obchody-miedzynarodowego -dnia-pamieci-o-ofiarach-holokaustu-w-rzeszowie

128 http://www.niedziela.pl/artykul/110588/nd/Miedzynarodowy-Dzien-Pamieci-o-Ofiarach [30.12.2015], ttp://www.pwste.edu.pl/aktualnosci/zycie-uczelni/1813-vi-obchody-miedzy narodowego-dnia-pamieci-o-ofiarach-holokaustu-w-rzeszowie [30.12.2015].
} 
wości, wykłady popularnonaukowe, pokazy filmowe i koncerty ${ }^{129}$. Podobnie do głównych uroczystości silny akcent położony jest na pamięć o lokalnych Sprawiedliwych wśród Narodów Świata (w 2015 r. Kolbuszowej m.in. zaprezentowano sylwetki osób odznaczonych medalem „Sprawiedliwych wśród Narodów Świata ${ }^{130}$, w Krośnie wykład prof. Elżbiety Rączy poświęcony został Polakom ratujących Żydów w Krośnie i regionie krośnieńskim ${ }^{131}$ ).

Międzynarodowy Dzień Pamięci o Ofiarach Holokaustu obchodzony jest na Podkarpaciu od 6 lat. Organizowany jest głównie przez instytucje samorządowe i rządowe lub w ścisłej z nimi współpracy, przy dużym zaangażowaniu Kościoła katolickiego i organizacji społeczno-kulturalnych. Częścią oficjalną uroczystości i jej „kulminacyjnym punktem”132, „zwieńczeniem obchodów" 133 jest zazwyczaj nabożeństwo odprawiane w kościele katolickim, w czasie którego odczytywane są nazwiska Polaków ratujących Żydów i Żydów przez nich ratowanych. Główny akcent upamiętnienia położony jest na pamięć o polskich „Sprawiedliwych wśród Narodów Świata". Nie bez znaczenia w tym kontekście była decyzja Sejmiku Województwa Podkarpackiego z 2008 r. uchwalająca, że w Markowej powstanie lokalne Muzeum Polaków Ratujących Żydów na Podkarpaciu im. Rodziny Ulmów oraz zaplanowane na marzec 2016 r. otwarcie ogólnopolskiego już w charakterze Muzeum Polaków Ratujących Żydów podczas II wojny światowej im. Rodziny Ulmów ${ }^{134}$. Otwarcie tego muzeum odbyło się zgodnie $\mathrm{z}$ planem.

Stołeczne obchody Międzynarodowego Dnia Pamięci o Holokauście, obchodzone od 2006 r., organizowane są głównie przez Fundację Shalom (działającą na rzecz „ocalenia od zapomnienia bogatego dziedzictwa kultury jidysz" ${ }^{135}$ ). Miały one również swój stały scenariusz. Honorowy patronat nad nimi obejmowała głównie Prezydent Warszawy Hanna Gronkiewicz-Waltz.

129 http://ipn.gov.pl/_data/assets/pdf_file/0005/137966/Afisz_30_12_2014-2.pdf [30.12.2015].

130 http://www.kolbuszowa.pl/20-aktualnosci/55-aktualnosci/379-kolbuszowskie-obchodymiedzynarodowego-dnia-pamieci-o-ofiarach-holokaustu.html [01.01.2016].

131 http://ipn.gov.pl/aktualnosci/2015/rzeszow/obchody-miedzynarodowego-dnia-pamiecio-ofiarach-holocaustu-na-podkarpaciu-krosno-rzeszow-kolbuszowa-jaroslaw-lubaczow,-26 29-stycznia-2015 [01.01.2016].

132 A. Kulczycka, Zaczynamy od Kadiszu...

133 L. Szura, Srebrna łyżeczka jak metryka...

134 http://www.podkarpackie.pl/index.php/biuro-prasowe/przegld-mediow/77-www / 28 55-kamien-wegielny-pod-muzeum-polakow-ratujacych-zydow-poswiecony-przez-papieza -franciszka [28.12.2015].

135 Warszawa Singera. XII Festiwal Kultury Żydowskiej 22-30.08.2015. Program, Warszawa 2015, s. 119. 
Oficjalne uroczystości odbywały się pod pomnikiem Bohaterów Getta ${ }^{136}$. Reprezentanci władz państwowych i samorządowych, korpusu dyplomatycznego, organizacji społecznych, różnych wyznań i kościołów składali tam wieńce i uczestniczyli w modlitwie ekumenicznej. Podczas Apelu Pamięci, który odbywał się od 2011 r. na ul. Próżnej, odczytywane były imiona tych, którzy zginęli w Holokauście: rodzin, przyjaciół, znajomych, sąsiadów. Ceremoniom oficjalnym towarzyszyły obchody o charakterze artystycznym: koncerty, spektakle (65. i 70. rocznicę uświetnił udział Izraelskiej Orkiestry Symfonicznej, a pod pomnikiem Bohaterów Getta odbyła się „Azkara dla Pamięci" - symboliczne upamiętnienie bojowników powstania w getcie warszawskim) ${ }^{137}$. Pusty tramwaj, oznaczony gwiazdą Dawida, jeżdżący ulicami Warszawy miał przypominać jej mieszkańcom o ich sąsiadach, którzy zginęli w obozach zagłady i gettach. Upamiętnieniem ofiar Holokaustu było również Światło Pamięci - apel o zapalenie świec w domach i wirtualnie - w Internecie $^{138}$. W porównaniu $\mathrm{z}$ obchodami rzeszowskimi uroczystości warszawskie poświęcone były przede wszystkim żydowskim ofiarom Holokaustu, Kościół katolicki był jednym z uczestników obchodów, wraz z innymi kościołami i wyznaniami, a nie jednym z głównych organizatorów. Oficjalnym obchodom towarzyszyły głównie uroczystości o charakterze artystycznym.

Pamięć o zagładzie Żydów w czasie II wojny światowej jest obecnie na Podkarpaciu widocznym oraz ważnym przejawem istnienia przeszłości w dyskursie publicznym, mimo że dopiero od niedawna uzyskuje właściwą rangę. Wpisuje się $\mathrm{w}$ charakterystyczny dla współczesności nurt powrotów do przeszłości, „renesansu upamiętnień”, którego jednym z przejawów jest "nawrót do historii w swych regionalnych i lokalnych wymiarach" 139.

Pamięć ta jest pamięcią przywracaną, wydobywającą przeszłość z zapomnienia (upamiętnienie "Sprawiedliwych wśród Narodów Świata” w Rymanowie 2011, upamiętnienie cmentarza żydowskiego w Rzeszowie 2006, upamiętnienie getta krośnieńskiego 2015) oraz przynajmniej w pewnym zakresie - pamięcią krytyczną, próbującą się mierzyć z historią trudną (coroczny

\footnotetext{
136 Tamże, s. 120.

137 Tamże, s. 120.

138 http://shalom.org.pl/projects/miedzynarodowy-dzien-pamieci-o-ofiarach-holokaustu/, http://wyborcza.pl/1,91446,17314305,Warszawa_uczci_X_Miedzynarodowy_Dzien_Pamieci _o_Ofiarach.html, http://shalom.org.pl/event/warszawskie-obchody-ix-miedzynarodowe go-dnia-pamieci-o-ofiarach-holokaustu/, http://shalom.org.pl/event/viii-miedzynarodo wy-dzien-pamieci-o-ofiarach-holokaustu/, http://shalom.org.pl/event/vi-miedzynarodo wy-dzien-pamieci-o-holokauscie/ [01.01.2016].
}

139 K. Malicki, Upamiętnienie przeszłości, jako źródło konfliktów..., s. 47. 
udział proboszcza Gniewczyny w obchodach Międzynarodowego Dnia Pamięci o Ofiarach Holokaustu, debata studencka Ocena postaw Polaków wobec Żydów w czasie niemieckiej okupacji Jarosław 2015).

Jest pamięcią społeczną, oddolną (Marsz Żywych i Dni Pamięci o Żydowskiej Społeczności Rymanowa) - uroczystości upamiętniające organizowane są przez stowarzyszenie i osoby prywatne: społeczników, regionalistów, których głównym celem działalności jest pielęgnowanie pamięci wielokulturowości (Rymanów) lub pamięci o zagładzie Żydów w danym mieście (Rzeszów). Do tych upamiętnień niejako dołącza pamięć scentralizowana, kształtowana odgórnie przez instytucje państwowe i samorządowe. Ta pamięć, to głównie pamięć o Polakach jako narodzie porównywalnie do Żydów doświadczonym przez Niemców w czasie II wojny światowej (wystąpienia prezydenta Miasta Rzeszowa podczas V i IX Marszu Żywych w Rzeszowie) lub pamięć o Polakach niosących pomoc prześladowanym Żydom (Międzynarodowy Dzień Pamięci o Ofiarach Holokaustu).

Kościół katolicki jako instytucja pamięci celebruje niemal wszystkie (za wyjątkiem Marszu Żywych) uroczystości służące upamiętnieniu Holokaustu na Podkarpaciu. W przypadku obchodów Międzynarodowego Dnia Pamięci o Ofiarach Holokaustu jest jednym z organizatorów uroczystości, a nabożeństwo połączone z odczytaniem nazwisk Polaków ratujących Żydów i Żydów zamordowanych wraz z Polakami jest punktem kulminacyjnym wszystkich obchodów.

Rocznicowe obchody pamięci o Holokauście przekazują bądź utrwalają ich uczestnikom (głównie Żydom pochodzącym z danych miejscowości lub/i ich potomkom oraz miejscowej młodzieży gimnazjalnej i studentom) wiedzę o bogatej i często tragicznej historii Podkarpacia jako regionu wieloetnicznego i wielokulturowego. Przynoszą informacje o zagładzie Żydów, jako o wydarzeniu, które zakończyło historię Żydów na Podkarpaciu, jej skali, ofiarach i skutkach $\mathrm{w}$ regionie, mieście i jego okolicy, z głównym akcentem położonym na rolę, jaką odegrali polscy, lokalni Sprawiedliwi wśród Narodów Świata w ratowaniu tamtejszych Żydów. To jest również główny przekaz wynikający z obchodów rocznicowych upamiętniających Holokaust na Podkarpaciu, a jednocześnie „odpowiedź na poszukiwanie tożsamości, z zapałem i obawą, [która] jest jednym z podstawowych działań dzisiejszych jednostek i społeczeństw" 140 .

140 J. Le Goff, Historia i pamięć, Warszawa 2007, s. 155. 


\title{
Remembrance of the Holocaust in Podkarpacie at the beginning of the 21st century exemplified by anniversary celebrations
}

\begin{abstract}
The article analyses how the Holocaust is becoming an element of collective memory of today's residents of Podkarpacie. On the basis of the typology of widely understood collective memory and the presentation of sociological research results indicating how in practice the remembrance of the Holocaust functions in the awareness of Podkarpacie selected social groups, an attempt has been made at the analysis of ways of commemorating the Holocaust and its victims on the basis of local anniversary celebrations: the March of the Living (Rzeszów), Days of Memory of Rymanów Jews (Rymanów) and International Day of Commemoration in Memory of the Victims of the Holocaust (Rzeszów, Jarosław, Lubaczów, Krosno and Kolbuszowa). On the basis of the analysis, it may be claimed that the memory of the Holocaust in Podkarpacie is an important manifestation of the existence of the past in the public discourse. It is mainly grassroots and social memory which somehow encloses centralized memory developed by state and local government institutions. It is generally the memory of the Polish nation that has been most severely persecuted by the Germans during World War II as well as the memory of the Poles helping persecuted Jews.
\end{abstract}

Key words: collective memory, the Holocaust, Podkarpacie, anniversary celebrations

\section{Память о Холокосте на Подкарпатье в начале XXI века на примере ежегодных празднований}

\section{Абстракт}

Статья анализирует причину, по которой Холокост становится элементом общенародной памяти жителей Подкарпатья. Основываясь на типологии общенародной памяти, в широком понимании этого слова, и результатах социологического исследования, указывающего на то, как на практике функционирует память о Холокосте в сознании общественных групп Подкарпатья, авторы проанализировали причины, благодаря которым жива память о Холокосте и его жертвах. Аоказательством памяти о Холокосте являются: Марш Живых (Жешов), Ани памяти еврейской общины Рымянова (Рымянув), Международный день памяти о жертвах Холокоста (Жешув, Ярослав, Аюбачув, Кросно, Колбушова). Анализируя это, авторы пришли к выводу, что память о Холокосте на Подкарпатье является важным доказательством того, что прошлое до сих пор сохранилось в публичном 
дискурсе. Это общенародная память, к которой как будто присоединяется память централизованная, сформированная под влиянием государственных и муниципальных учреждений. В основном, это память о польском народе, сильно пострадавшем во время Второй Мировой войны, о поляках, которые помогали евреям, подвергавшимся преследованиям.

Ключевые слова: общенародная память, Холокост, Подкарпатье, ежегодные празднования

\section{Bibliografia}

A.G., Marsz żywych. Rzeszów wciąż pamięta, "Gazeta Wyborcza - Rzeszów" 07.07.2008. Adamski A., W parku będzie miejsce pamięci, "Nowiny” 07.07.205.

Adamski A., Żyjemy, aby pamiętać, „Nowiny” 10.07.2006.

Adamski A., Żyjemy, aby pamiętać, „Nowiny” 10.07.2006.

ASK, Rzeszów pamięta o ofiarach Holocaustu, „Gazeta Wyborcza - Rzeszów” 28.01.2011. Assmann A., Między historiq a pamięciq. Antologia, Warszawa 2013.

Assmann J., Pamięć kulturowa. Pismo, zapamiętywanie i polityczna tożsamość w cywilizacjach starożytnych, tłum. A. Kryczyńska-Pham, Warszawa 2008.

Bojarska K., Zagłada [w:] Modi Memorandi. Leksykon kultury pamięci, red. M. Saryusz-Wolska, R. Traba, Warszawa 2014.

Bojarska M., Międzynarodowy Dzień Pamięci o Ofiarach Holokaustu, „Niedziela” 16.02. 2014.

Doktór J., Menachem Mendel z Rymanowa [w:] Polski słownik judaistyczny. Dzieje, kultura, religia, ludzie, red. Z. Borzymińska, R. Żebrowski, t. 2, Warszawa 2003.

Gernand A., Znak pamięci, „Gazeta Wyborcza - Rzeszów” 30.05.2005.

Gorczyca A., Dni pamięci w Rymanowie, „Gazeta Wyborcza - Rzeszów” 13.08.2015.

Gorczyca A., Marsz Pamięci, „Gazeta Wyborcza - Rzeszów” 08.07.2006.

Gorczyca A., Marsz tych, co pamiętaja i chca pamiętać, "Gazeta Wyborcza - Rzeszów” 06.07.2006.

Gorczyca A., Pamięci ofiar Holocaustu, „Gazeta Wyborcza - Rzeszów” 27.01.2015.

Gorczyca A., Przyjechali na szabat do Rymanowa, "Gazeta Wyborcza - Rzeszów” 12.08.2010.

Gorczyca A., Rymanów uczci Żydów i Polaków, którzy im pomagali, „Gazeta Wyborcza - Rzeszów" 10.08.2009.

Gorczyca A., Trzeba przypominać, że żyli tu Żydzi, „Gazeta Wyborcza - Rzeszów” 06.07.2012.

Gorczyca A., Uczcza pamięć rymanowskich Żydów, „Gazeta Wyborcza - Rzeszów” 12.08.2008.

Gorczyca A., W Rymanowie: Radość wesela i zaduma wspomnień, „Gazeta Wyborcza Rzeszów" 11.08.2011. 
Kaczmarski K., Pogrom, którego nie było. Rzeszów, 11-12 czerwca 1945 r. Fakty, hipotezy, dokumenty, Rzeszów 2008.

Kapralski S., Od milczenia do "trudnej pamięci". Państwowe Muzeum Auschwitz-Birkenau i jego rola w dyskursie publicznym [w:] Następstwa zagłady Żydów. Polska 1944-2010, red. F. Tych, M. Adamczyk-Garbowska, Lublin 2011.

Kończal K., Miejsce pamięci [w:] Modi Memorandi. Leksykon kultury pamięci, red. M. Saryusz-Wolska, R. Traba, Warszawa 2014.

Kulczycka A., Ożywić pamięć o ofiarach Holocaustu, „Gazeta Wyborcza - Rzeszów” 28.01.2009.

Kulczycka A., Świadek opowiada o Holocauście, „Gazeta Wyborcza - Rzeszów” 21.01. 2009.

Kulczycka A., Zaczynamy od Kadiszu..., „Gazeta Wyborcza - Rzeszów” 25.01.2011.

Kwiatkowski P. T., Pamięć zbiorowa społeczeństwa polskiego w okresie transformacji, Warszawa 2008.

Le Goff J., Historia i pamięć, Warszawa 2007.

Lucy, Pamiętamy o ofiarach Holocaustu, "Gazeta Wyborcza - Rzeszów” 26.01.2010.

Malicki K., Pamięć przeszłości pokolenia transformacji, Warszawa 2012.

Malicki K., Polacy i ich pamięć przeszłości. Studium socjologiczne pamięci zbiorowej na przykładzie regionu podkarpackiego, Kraków 2012.

Malicki K., Upamiętnienie przeszłości jako źródło konfliktów w przestrzeni symbolicznej regionu podkarpackiego, [w:] Pamięć zbiorowa jako czynnik integracji i źródło konfliktów, red. A. Szpociński, Warszawa 2009.

Markiel T., Skibińska A., Zagłada domu Trynczerów, Warszawa 2011.

Marsz żywych, „Tygodnik Extra” 20.07.2006.

Rączy E., Zabójstwa dokonane na Żydach w województwie rzeszowskim w latach 1944-1947 w świetle akt organów bezpieczeństwa [w:] Z dziejów stosunków polsko-żydowskich w XX wieku, red. E. Czop, E. Rączy, Rzeszów 2009.

Rączy E., Zagłada Żydów w dystrykcie krakowskim w latach 1939-1945, Rzeszów 2014.

Rymanów [w:] The Yad Vashem Encyclopedia of the Ghettos during the Holocaust, red. G. Miron, t. II, Jerusalem 2009.

Rzeszów [w:] The Yad Vashem Encyclopedia of the Ghettos during the Holocaust, red. G. Miron, t. II, Jerusalem 2009.

Stankowski A., Weiser P., Demograficzne skutki Holokaustu, [w:] Następstwa zagłady Żydów. Polska 1944-2010, red. F. Tych, M. Adamczyk-Garbowska, Lublin 2011.

Staszewska K., Marsz upamiętniajacy likwidację rzeszowskiego getta, „Gazeta Wyborcza - Rzeszów" 07.07.2014.

Sułek A., Zwykli Polacy patrza na Żydów. Postawy społeczeństwa polskiego wobec Żydów w świetle badań sondażowych (1967-2008), [w:] Następstwa zagłady Żydów. Polska 1944-2010, red. F. Tych, M. Adamczyk-Garbowska, Lublin 2011.

Szura L., Srebrna tyżeczka jak metryka, „Gazeta Wyborcza - Rzeszów” 28.01.2010. 
Thomas K., Pracownia Historii i Kultury Żydów Instytutu Historii Uniwersytetu Rzeszowskiego, [w:] Studia żydowskie w Polsce - przeszłość, stan obecny, perspektywy. Studium selektywne, red. S. Gąsiorowski, Kraków 2014.

Tournelle-Krynicka de K., Moshe poprowadził marsz pamięci, „Super Nowości” 10.07. 2006.

Upamiętnili rzeszowskich Żydów, „Super Nowości” 08-10.07.2005.

Warszawa Singera. XII Festiwal Kultury Żydowskiej 22-30.08.2015. Program, Warszawa 2015.

Wasiutyński B., Ludność żydowska w Polsce w wiekach XIX i XX. Studjum statystyczne, Warszawa 1930.

Wierzbieniec W., Miejsca pamięci rzeszowskich Żydów [w:] Encyklopedia Rzeszowa, red. Z. Budzyński, Rzeszów 2004.

Wierzbieniec W., Żydzi rzeszowscy, [w:] Encyklopedia Rzeszowa, red. Z. Budzyński, Rzeszów 2004.

Woniak K., Pamięć lokalna, [w:] Modi Memorandi. Leksykon kultury pamięci, red. M. Saryusz-Wolska, R. Traba, Warszawa 2014.

Wacław Wierzbieniec - dr hab. prof. UR, kierownik Zakładu Historii i Kultury Żydów w Instytucie Historii Uniwersytetu Rzeszowskiego, pracuje też w Państwowej Wyższej Szkole Techniczno-Ekonomiczna im. ks. Bronisława Markiewicza w Jarosławiu, członek m.in.: Komisji Historii i Kultury Żydów Polskiej Akademii Umiejętności w Krakowie, Wojewódzkiego Komitetu Ochrony Pamięci Walk i Męczeństwa w Rzeszowie i Rady Naukowej czasopisma „Studia Judaica”.

e-mail: wacwie@univ.rzeszow.pl

Magdalena Prokopowicz - mgr historii, doktorantka Instytutu Historii Uniwersytetu Rzeszowskiego. Pracuje Muzeum Historii Żydów Polskich POLIN.

e-mail: mprokopowicz@polin.pl 